\title{
Study on the Resource Conception of Ideological and Political Theory Courses of Higher Education
}

\author{
Jianli Wang \\ Department of Social Sciences \\ Tangshan College \\ Tangshan, China
}

\begin{abstract}
The article depends on the existing research results and practical experience on explanation about the correlation theory of the resource of university ideological and political theory courses, tries to draw the basic prospect of the new course resource conception and builds effective supporting platform through reviewing and reflecting on the existing outlook of curriculum resources of middle school ideological and political education in our country. And then it puts forward strategies and advice about the integration and use of course resources under the new outlook of curriculum resources.
\end{abstract}

Keywords-ideological and political theory course; curriculum resources; integration and utilization

\section{IdeOlogicAl AND Political TheORy COURSE AND THE CONNOTATION OF CURRICULUM RESOURCE}

As the main channel and main platform of the systematic ideological and political education for college students, the teaching of ideological and political theory course plays an important role in the aspect of cultivating college students into builders and successors of the socialist course. There are broad sense and narrow sense in understanding the teaching practice of the ideological and political course in higher education. "In terms of the generalized concept, all the active activities which combine subjective understanding with objective things can be regarded as practical activities. Then the teaching of the university ideological and political theory course is the summation of teaching activity which combines subjective understanding with objective things." [1] It not only includes in-class activities such as classroom teacherstudents interaction, classroom discussion, etc., but also includes extra-curricular activities out of the classroom, such as the extracurricular teaching activities such as social survey, practice teaching, etc. From the perspective of the concept of narrow sense, it refers in particular to the correspondent concepts and teaching methods of theory teaching in classroom, cultivates their abilities of understanding and analyzing problems, social sense of responsibility and sense of mission in class, and further internalizes knowledge into moral sentiments to improve the moral cultivation of students. From the perspective of the integration and utilization of teaching resources and teaching practice, the understanding of ideological and political theory course of this article is that we should regard the concept of narrow sense of ideological and political theory course as the core, give consideration to extra-class education and teaching activities at the same time, strengthen students' understanding of the basic theory of ideological and political theory course and then achieve the goal of firming the political stand of the students and improve their moral cultivation through the close combination of theory and practice. In other words, in education activities of paying attention to knowledge system, we should as well lay emphasis on useful resources of related to the knowledge system of this course, use all kinds of effective means to place students in the broad social class, combine class knowledge and social practice, open up the channel for learning ideological and political theory course, enrich learning style, transfer students' learning for ideological and political theory course from passively acceptance to active participation to improve the teaching efficiency of ideological and political theory course.

Curriculum resource is an important concept put forward in course reform, there is a part of the "exploitation and utilization of curriculum resource" in curriculum standards of various subjects issued by the nation. The meaning of course resource is broad, it includes the teaching material as the important course resource known well by people, and it as well includes a good deal of the hardware and software resources of organic elements and implementation condition of course which are not teaching materials. No matter the exploitation of national curriculum or the construction of local course, especially the diversified presentation and mode of execution of combination of practical activities and school-based courses, it can't do without the support of a large number of curriculum resources. At present, the curriculum widely accepted refers to resources of forming the course elements and the necessary and direct conditions of operational curriculum. For example, the elements of aspects such as knowledge, skills, experience, activity mode, emotional attitude and moral values, and training objective, etc. are the resource of curriculum elements. However, the elements such as the human, material and financial resources, time, the site and medium, equipment, facilities and conditions directly deciding the curriculum implementation scope and level, and the condition of understanding the courses belong to the implementation condition of the curriculum. [2] The understanding of course resources in the past mainly consider from the perspective of object, and it thinks course resources are textbooks and reference books, 
etc. In reality, it is a very on-sided understanding. Because from the perspective of the implementation of course objectives, all the factors good for curriculum implementation should belong to course resources, not only including the material resources such as textbooks, reference books and teaching places, etc, but also including human resources such as subject specialist, teachers and students, etc. [3] The integration and use of course resources should be comprehensive and scientific, make all of these factors well serve the teaching to promote the implementation of teaching objectives. Specific to the process of practical teaching of ideological and political theory course, all the element resources used by practical teaching of ideological and political theory course and course resources as necessary and direct implementation condition for implementing practical teaching of ideological political theory course, such as teaching materials of ideological and political course, relevant material object, sites and relics of revolutionary history, all kinds of movie and video materials of history and reality, human landscapes and natural landscape containing rich contents, social production and social life, etc. all can be used as course resources of the practical teaching of ideological and political theory course. These resources are essential requirements and conditions to ensure the practical teaching of ideological and political course. The richness and applicability of the course resources of practical teaching of ideological and political theory course largely decide the scope of implementation and implementation level of course objectives.

\section{The Dialectical Relationship BetweEN IDEOLOGICAL AND PoliticAl TheOry COURSE AND COURSE RESOURCES}

Curriculum is the core part of school educational activities. At present, the Word-Ocean, Encyclopedia of China and many teaching materials of Pedagogy all think curriculum is subject, or refers to the sum and progress arrangement of the contents learned by students on school days namely the generalized course, or a certain subject namely the course of narrow sense. Curriculum resources and curriculum have a very close relationship. If there are no curriculum resources, there is no curriculum. And curriculum must have curriculum resources as precondition. Curriculum resource is not the resource mechanically serving course objectives. It is not only the resource of course contents, but also the resource of producing course objectives and forming the idea of course design and it has autonomy and motility for curriculum activities. The course reform makes the subject teaching of new course develop from oneness to synthesis and must attaches importance to the exploitation and use of resources.

The ideological and political theory course in our country integrates ideological level, knowledge and practical intelligence, directly manifests the basic requirements our country has on the aspect of ideological and political quality of college students and the aspect of social science knowledge, also reflects the mainstream thoughts of social ideology in our country. Through the learning of ideological and political theory course, students should receive comprehensive cultivation on the aspects such as ideological and political qualities, philosophy quality, moral ideas, legal awareness, economic mind and state concept, etc. as well as the aspects such as the competence in solving problems, the ability of subject study, the ability of social survey, etc. This shows that the task of ideological and political theory course is very difficult, but the space to develop and use the resources of ideological and political theory course is very broad. Therefore, the relevant managers and implementers engaging in the teaching of ideological and political theory course should positively develop and make full use of all kinds of course resources and improve the use ratio and utilization level of course resources on the basis of defining connotation and extension of practical teaching resources. And on this basis they should further expand course resources to improve teaching efficiency of ideological and political theory course.

\section{THE SCOPE AND CATEGORY OF RESOURCES OF IDEOLOGICAL AND POLITICAL THEORY COURSE}

The scientific and reasonable integration and use of the resources of ideological and political theory course as an important part of the overall teaching practice from universities play an important role in improving teaching efficiency and teaching quality. So it is very necessary to define the scope and category of resources of ideological and political theory course. The generalized curriculum resources refer to various factors in favor of realizing the course objectives, while the curriculum resources of narrow sense only refers to the direct sources of teaching contents. Comprehensively speaking, curriculum resources refer to the sources of factors of forming course and the necessary and direct conditions of implementing courses.

The resources of ideological and political theory course have various classifications. But no matter adopting what point of view to divide the types of curriculum resources, we should pay attention to two basic principles. The first is the principle of logic. The divisiory curriculum resources types cannot be self-contradiction and have too many cross and overlap. The second is advantage principle. It is not only useful to analyze and solve main problems existing in school practice, but also in favor of the development and use of our curriculum resources to find corresponding solution channels and methods. As long as grasping the two basic principles, we can build more practical and effective analysis framework according to this. The composition of the resources of ideological and political course is very complicated. We can divide the resources of ideological and political theory course into different types according to different standards.

According to the space distribution of the resources of ideological and political theory course, it can be divided into curriculum resources on campus and the curriculum resources outside school. The resources of ideological and political course on campus include a variety of places and facilities such as library, laboratory and playground, etc. inside the school; human resources such as campus culture, relations between students and teachers, class organization, students' association, school spirit and learning style, etc. 
and various activities such as lecture, discussion, informal discussion and athletic contest implemented in school. The curriculum resources outside school is very extensive, such as students' family environment, the cultural quality of parents, the living environment of communities, public cultural facilities, local conditions and customs, abundant natural resources, parents, relevant persons in communities, etc. All of them belong to curriculum resources outside school. [7] The resources of ideological and political curriculum in and outside school are essential for school curriculum. The curriculum resources on campus are the most basic and the most convenient form of resources. The curriculum resources outside school have more effect of auxiliary and supplement. In the past, in the aspect of developing and using curriculum resources, the view of school is more limited in the campus so the curriculum resources outside school cannot be exploited and used fully. Therefore, based on the general background of curriculum reform of the current basic education, we should give consideration to the exploitation and use of curriculum resources both in and outside school and attach great importance to strengthen the interrelation between two of them, promote the bilateral communication and sharing to provide strong support and guarantee for students' overall development.

On the basis of the existing form of resources of ideological and political theory course, it can be divided into curriculum resources in materialized form and the curriculum resources not in materialized form. [8] The curriculum resources in materialized form are tangible material existence which can be seen and touched. Various forms of material objects entering the school curriculum areas such as the printed material giving priority to the textbooks, electronic audio and video products, all kinds of facilities, instruments, multimedia internet, etc. form the conditional factors of implementing curriculum; on the other hand, many people participating in school curriculum such as students, teachers, education managers at all levels, education researchers, parents and other social people are the condition to ensure the implementation of school curriculum and form the main body of development and utilization of curriculum resources. The curriculum resources not in materialized form mainly include knowledge, time, value, ethical norms, standards of behavior, activities of various forms, the interactions between teachers and students, various kinds of environment become the contents of school curriculum or influence the implementation of school curriculum in different ways.

According to mode of action of the resources of ideological and political theory course, it can be divided into the dominant curriculum resources and recessive curriculum resources. [6] The dominant curriculum resources refers to the resources that directly have effect on school curriculum, such as teaching equipment, knowledge, time and teachers, etc. The dominant curriculum resources can directly become the contents of school curriculum or convenient means of implementation, and comparatively speaking it is easy for us to develop and use. The recessive curriculum resources refer to the resources that have influence on school curriculum in potential forms, such as students' family atmosphere, social morality, interpersonal relationship, etc. Because the mode of action of recessive curriculum resources is indirect and convert, teachers and schools need to make reduplicated efforts to develop and use them.

According to the functional characteristics of the resources of ideological and political theory course, the curriculum resources can be divided into material resources and conditional resources. The features of material resources include acting on curriculum and becoming the material or source of curriculum. And it is the object for students to learn and gain. For example, the factors of aspects such as knowledge, skills, experience, activity ways and methods, emotional attitude and value and training objective belong to material resources. The features of conditional resources include acting on curriculum but not the direct source forming curriculum and they are not the direct objects for students to learn and gain. But it decides the implementation scope and level of curriculum to a large extent. For example, the factors such as human, material and financial resources, time, site, media, equipment, facilities and environment directly deciding the implementation scope and level of curriculum belong to conditional curriculum resources. Of course, dividing curriculum resources into material resources and conditional resources is for convenience of explaining the problem. There is no absolute boundary line between them. Many curriculum resources in reality always often include not only the materials of curriculum, but also the conditions of curriculum, such as the resources of library, museum, laboratory, internet, manpower and environment, etc. On the basis of other standards, the resources of ideological and political theory course can be divided into corresponding types and here we will not mention them one by one.

\section{The Necessity to INTEGRATE AND UsE the Resources Of IDEOLOGICAL AND POLITICAL THEORY COURSE}

\section{A. Meet the Needs of the Curriculum Reform}

In order to strengthen the adaptation of curriculum for places, schools and students, the national education curriculum reform not only sets the planning framework of the national basic education course including the national curriculum, local curriculum and school-based curriculum, but also stresses that schools and teachers must implement the new curriculum creatively and form abundant teaching mode with good adaptability. The implementation of the goal of curriculum reform largely depends on the condition of the curriculum resources. More and more people realized that without the wide support of curriculum resources, even the best curriculum reform ideas are hard to become practical education results. The degree of richness and adaptability of curriculum resources decide the scope of implementation and implementation level of course objectives.

\section{B. The Need to Enrich Teaching Contents}

The ideological and political theory course has the characteristics of ideological level, sociality, practice and 
timeliness. New materials, new concept, new situation and new events are the signs of ideological and political course different from any other subject. While the content of ideological and political teaching material has relative hysteretic nature. Through integrating and using the resources of ideological and political theory course to supplement the content with era characteristics, it ensures the synchronous development of teaching contents and society and ensures the contents have close relationship with students' life and the real society and endows teaching contents with great appeal.

\section{The Need to Reform the Teaching Methods}

Scientific teaching methods can enlighten students' thoughts, develop students' intelligence, explore students' potency, and cultivate the good quality and habit of students' thinking and to make the teaching get twofold results with half effort. In the past, politics teaching continues to use the old model. And the rigid and timeworn teaching method cannot interest the students or only make students mechanically memorize some rules and regulations. The passive situation of teaching makes the teachers' labor hard to be recognized by students. The status of political subjects falls sharply and the input of the teaching of political lesson is more but the output is less. Now conforming to the changes and requirements of curriculum standards, researchstyle, experiential learning, cooperative type, information technology and the integration of subject teaching are the dominant ways of teaching activities advocated by us and practice also proves it has appropriate and promoting effects on the students' development. Therefore, on the basis of choosing various forms of teaching activities, teachers should exert themselves to reflect the dominant activity form. Teachers must exploit and integrate curriculum resources creatively in teaching and make teaching have close relationships with social practice, the major political life of our country, the major political events of international community and the ideological reality of students, keep up with the steps and beats of the era and enhance the attraction and appeal of this subject.

\section{The Need to Realize Teaching Objectives}

Curriculum standards have three dimensions of knowledge, ability, emotional attitudes and values to express course objectives and reflect the change from putting too much emphasis on knowledge-transference and subject system in the past to now paying more attention to students' capability development and emotion, attitude and value. Teaching activities are for the purpose of promoting students' comprehensive and harmonious development and enrich and update students' knowledge; it improves and develops students' abilities; at the same time it helps students to form and promote the correct emotion, attitude and values. In the above three-dimensional value goals, emotion, attitudes and values are the priority targets. Because the traditional curriculum view puts too much emphasis on cognition and neglects the functions of emotion and attitudes in learning, it confines the rich, vivid teaching activities to narrow and dull frame of cognitivism. This kind of teaching short of emotional connotation and full of reason make students widely feel that learning is boring and monotonous and make them lose the interest in learning. New curriculum standard improves emotion element to a new level and height to understand and endows it with important value orientation in course objective. What the teaching of ideological and political theory course faces is the living people with complex emotions. Compared with other disciplines, the goals that it must achieve are special and complex. It not only makes students understand the principles of important ideological and political views, but also transfers it into students' own ideological beliefs and fulfils the tasks of touching people, influencing people and educating people. Therefore, in the process of integrating curriculum resources, we should touch students' emotional point to enrich and improve their emotions and then they develop into people with healthy personality.

\section{CONCLUSION}

All in all, the integration and utilization of the resources of ideological and political theory course are of great importance in changing curriculum function and way of learning. On one hand, we can surpass the narrow teaching content to let the life and experience of teachers and students enter teaching process to make teaching "live"; on the other hand, we can change students' status in teaching from passive knowledge receiver to the joint constructor of teaching and then motivate students' learning enthusiasm and initiative. Meanwhile, we can also expand teachers' education views and change their educational concepts to better motivate teachers creative intelligence. So to speak the effect of the resources of ideological and political theory course is more important than ever before and still further highlights the importance and urgency of curriculum resources. Therefore, stressing the status and function of curriculum resources is an important idea and a difficult point in this article which need us to attach great importance to.

\section{REFERENCES}

[1] Li Shangmin. The Exploitation and Utilization of Practical Teaching Resources of Ideological and Political Theory Course in Universities $[\mathrm{J}]$. The Academic Journal of Wuxi Institute of Education, 3 (1) 20-25.

[2] Wu Gangping. The Basic Thoughts of Regular High School to Exploit and Use Curriculum Resources [J]. Contemporary Educational Science, 2003, 20（8） : 25-30.

[3] Xu Jicun, Duan Zhaobing, Chen Qiong. Discussion on Curriculum Resources and Its Exploitation and Utilization [J]. Subject Education, 2002 (2): 17-18.

[4] Wu Gangping. Exploring and Utilizing the Basic Thoughts of Curriculum Resources [J]. Contemporary Educational Science, 2003, 20 (8): 25-30.

[5] Shi Liangfang. Theory of Curriculum - the Basis, Principle and Problems of Curriculum [M]. Beijing: Education Science Press, 1996: 271.

[6] Written by Taylor, translated by Shi Liangfang. The Basic Principles of Curriculum and Teaching [M]. Beijing: People's Education Press, 1994: 31 .

[7] Fan Wei. The Implementation of Exploitation and Utilization of Comprehensive Practical Activity for Curriculum Resources [J]. Curriculum Research, 2002 (3): 32. 